ORNL/M-4600

OAK RIDGE NATIONAL LABORATORY

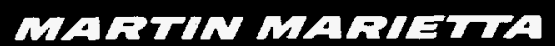

tact

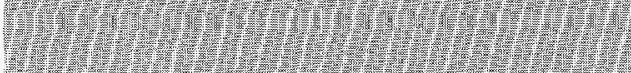

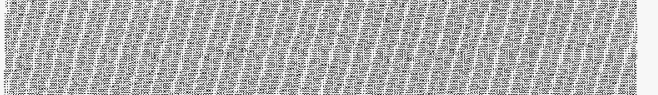
1. The T. 19.2) ……

\section{:} Pat

\section{.}

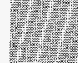

1.7.

\section{1.} 1) 1) Vives 1.t. P. W M

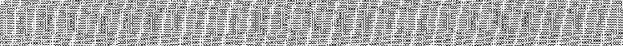

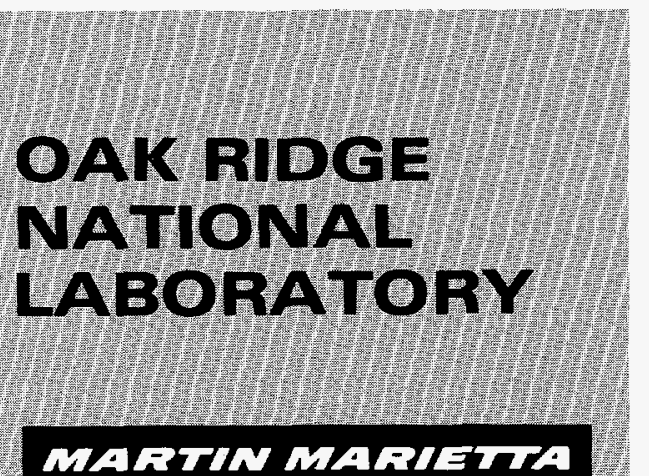

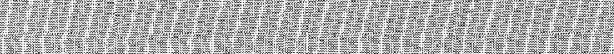

\section{MANAGED BY}

MARTIN MARIETTA ENERGY SYSTEMS, INC.

FOR THE UNITEO STATES

DEPARTMENT OF ENERG

\section{Finite Element Analysis of Advanced Neutron Source Fuel Plates}

\author{
C. R. Luttrell
}

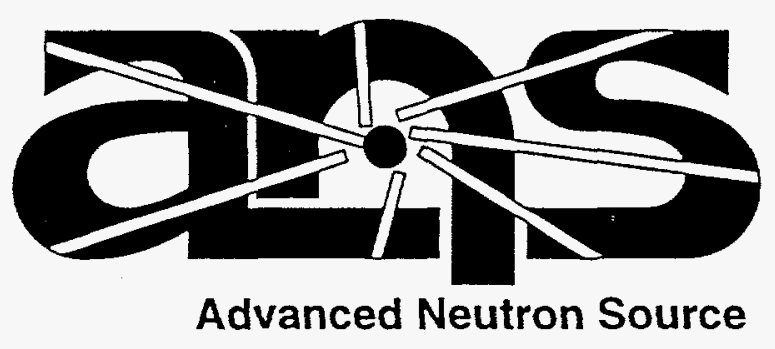

\section{MASTER}


This report has been reproduced directly from the best available copy.

Available to DOE and DOE contractors from the Office of Scientific and Technical Information, P.O. Box 62, Oak Ridge, TN 37831; prices available from (615) 576-8401, FTS 626-8401.

Available to the public from the National Technical Information Service, U.S. Department of Commerce, 5285 Port Royal Rd., Springfield, VA 22161.

This report was prepared as an account of work sponsored by an agency of the United States Government. Neither the United States Government nor any agency thereof, nor any of their employees, makes any warranty, express or implied, or assumes any legal liability or responsibility for the accuracy, completeness, or usefulness of any information, apparatus, product, or process disclosed, or represents that its use would not infringe privately owned rights. Reference herein to any specific commercial product, process, or service by trade name, trademark, menufacturer, or otherwise, does not necessarily constitute or imply its endorsement, recommendation, or favoring by the United States Government or any agency thereof. The views and opinions of authors expressed herein do not necessarily state or reflect those of the United States Government or any agency thereof. 


\title{
FINITE ELEMENT ANALYSIS OF ADVANCED NEUTRON SOURCE FUEL PLATES
}

\author{
C. R. Luttrell
}

Date published: August 1995

Prepared by OAK RIDGE NATIONAL LABORATORY

Oak Ridge, Tennessee 37831 managed by

LOCKHEED MARTIN ENERGY SYSTEMS, INC.

for the

U.S. DEPARTMENT OF ENERGY under contract DE-AC05-84OR21400 


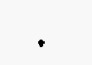

. 
LIST OF FIGURES $\ldots \ldots \ldots \ldots \ldots \ldots \ldots \ldots \ldots \ldots \ldots \ldots \ldots \ldots$

LIST OF TABLES $\ldots \ldots \ldots \ldots \ldots \ldots \ldots \ldots \ldots \ldots \ldots \ldots \ldots \ldots \ldots$ vii

ABSTRACT $\ldots \ldots \ldots \ldots \ldots \ldots \ldots \ldots \ldots \ldots \ldots \ldots \ldots \ldots \ldots \ldots \ldots \ldots$

1. INTRODUCTION $\ldots \ldots \ldots \ldots \ldots \ldots \ldots \ldots \ldots \ldots \ldots \ldots \ldots \ldots \ldots \ldots$

2. MILLER'S THEORY EXTENDED TO INVOLUTE PLATES $\ldots \ldots \ldots \ldots \ldots \ldots$

3. FLOW BLOCKAGE EFFECTS ON ADVANCED NEUTRON SOURCE FUEL

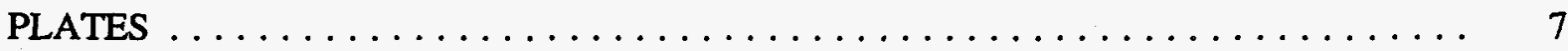

4. TEMPERATURE EFFECTS ON GAP BETWEEN ADVANCED NEUTRON

SOURCE FUEL PLATES $\ldots \ldots \ldots \ldots \ldots \ldots \ldots \ldots \ldots \ldots \ldots \ldots \ldots$

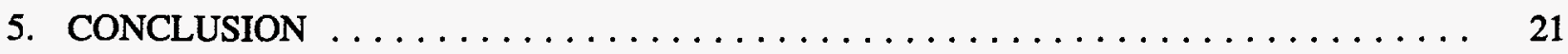

6. REFERENCES $\ldots \ldots \ldots \ldots \ldots \ldots \ldots \ldots \ldots \ldots \ldots \ldots \ldots \ldots \ldots \ldots \ldots \ldots$ 


\section{LIST OF FIGURES}

Figure

Page

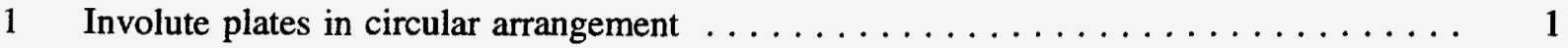

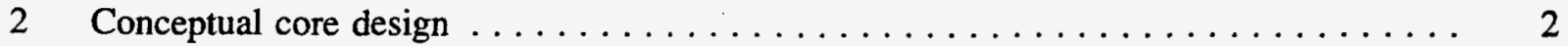

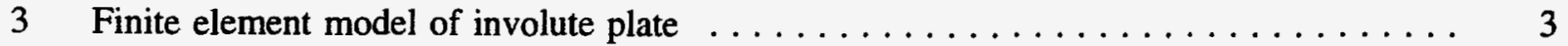

4 Finite element mesh for flow blockage $\ldots \ldots \ldots \ldots \ldots \ldots \ldots \ldots \ldots \ldots \ldots$

5 Pressure difference on fuel plate $\ldots \ldots \ldots \ldots \ldots \ldots \ldots \ldots \ldots \ldots \ldots \ldots$

6 Maximum principal stress on fuel plate $\ldots \ldots \ldots \ldots \ldots \ldots \ldots \ldots \ldots \ldots \ldots \ldots \ldots$

$7 \quad$ Finite element model for thermal analysis $\ldots \ldots \ldots \ldots \ldots \ldots \ldots \ldots \ldots \ldots \ldots$

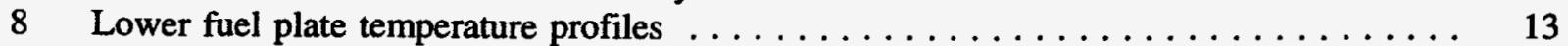

9 Upper fuel plate temperature profiles $\ldots \ldots \ldots \ldots \ldots \ldots \ldots \ldots \ldots \ldots \ldots \ldots$

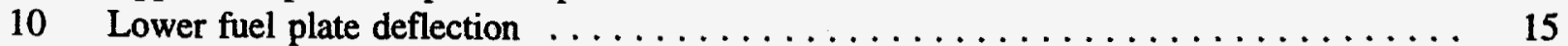

11 Upper fuel plate deflection $\ldots \ldots \ldots \ldots \ldots \ldots \ldots \ldots \ldots \ldots \ldots \ldots \ldots \ldots$

12 Axial stress in lower fuel plate $\ldots \ldots \ldots \ldots \ldots \ldots \ldots \ldots \ldots \ldots \ldots$

13 Axial stress in upper fuel plate $\ldots \ldots \ldots \ldots \ldots \ldots \ldots \ldots \ldots \ldots \ldots \ldots \ldots$

14 Tensile strength of 6061-T0 aluminum as a function of temperature . . . . . . . . 19 


\section{LIST OF TABLES}

1 Parameter study critical velocity $(\mathrm{m} / \mathrm{s}) \ldots \ldots \ldots \ldots \ldots \ldots \ldots \ldots \ldots$

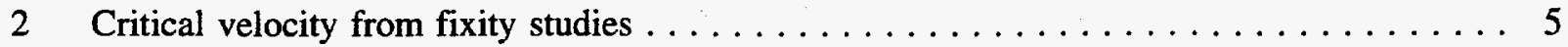

3 Lower plate comparison of change in gap between hot and cold plates $59 \mathrm{~mm}$

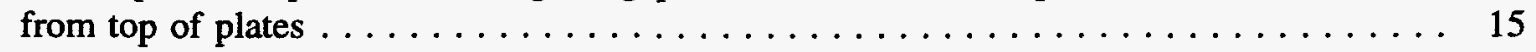

4 Upper plate comparison of change in gap between hot and cold plates $59 \mathrm{~mm}$ from top of plates 
. 


\begin{abstract}
The proposed design for the Advanced Neutron Source reactor core consists of closely spaced involute fuel plates. Coolant flows between the plates at high velocities. It is vital that adjacent plates do not come in contact and that the coolant channels between the plates remain open. Several scenarios that could result in problems with the fuel plates are studied. Finite element analyses are performed on fuel plates under pressure from the coolant flowing between the plates at a high velocity, under pressure because of a partial flow blockage in one of the channels, and with different temperature profiles.
\end{abstract}


$\because$ 


\section{INTRODUCTION}

One of the critical design regions of the Advanced Neutron Source Reactor (ANS) core is the closely spaced fuel plates. The proposed design for the ANS reactor uses involute fuel plates that allow the plates to be inserted in the core in a circular arrangement with a constant gap size (see Fig. 1). The conceptual core design consisted of a two-element core: an upper and a lower fuel element. ${ }^{1}$ Figure 2 shows the dimensions for the conceptual core design proposed for the ANS reactor at the time these analyses were performed.

It is vital that adjacent fuel plates in the core do not come in contact with each other and that coolant flow is maintained between the plates at all times. Several things could occur to cause the fuel plates to come in contact or to hinder the flow between the plates: (1) a pressure difference on the fuel plates due to the high velocity of fluid flowing between the fuel plates, (2) a flow blockage in one of the channels, or (3) a difference in thermal loads on adjacent plates, causing the gap between the plates to change, which in turn could effect the rate of heat transfer from the fuel plates.

Finite element analyses of these various load cases were performed to determine their effect. The finite element codes used for these analyses were ADINA and ABAQUS. ${ }^{2,3}$ The programs PATRAN and IDEAS were used for pre- and postprocessing.,

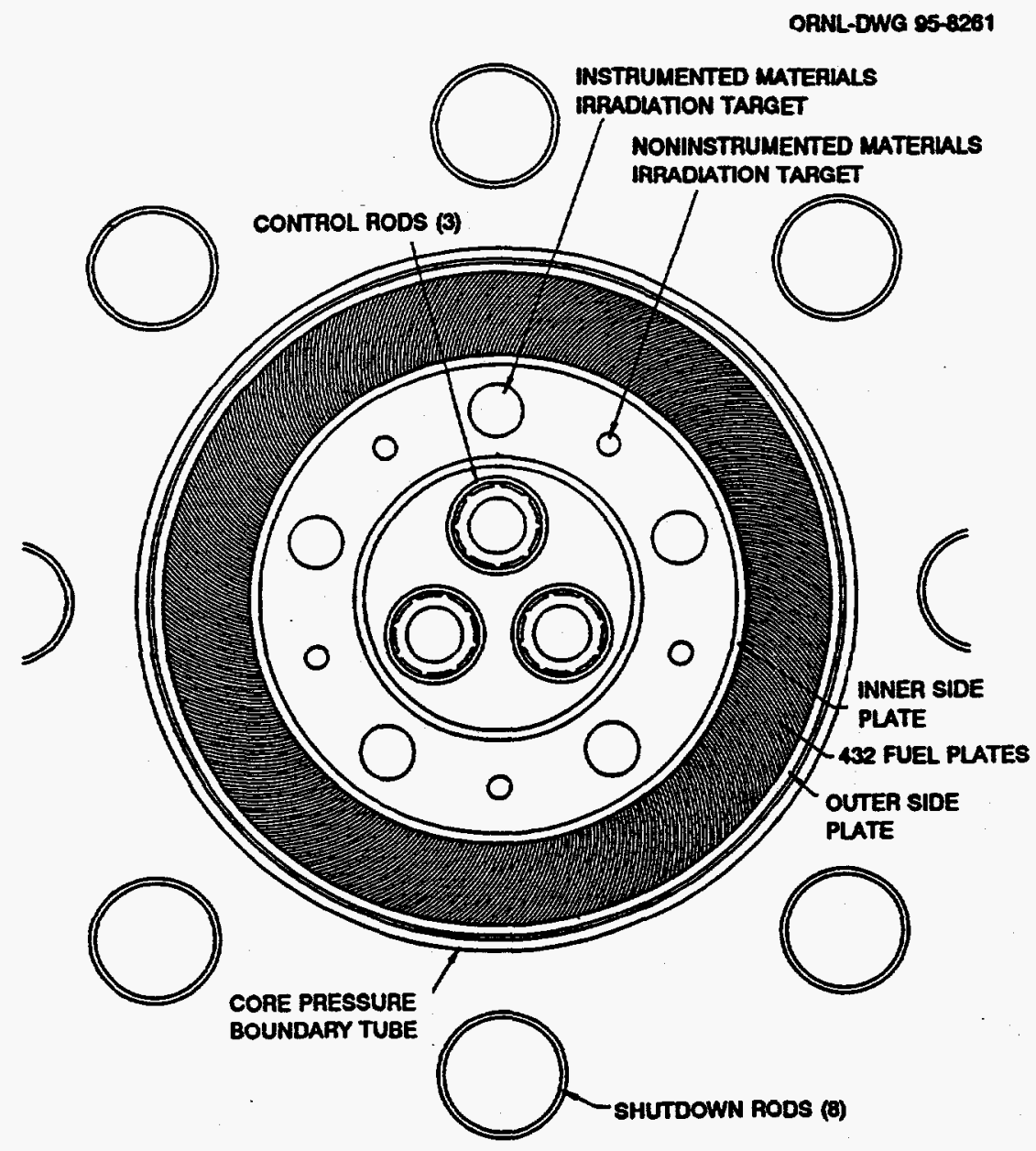

Fig. 1. Involute plates in circular arrangement. 


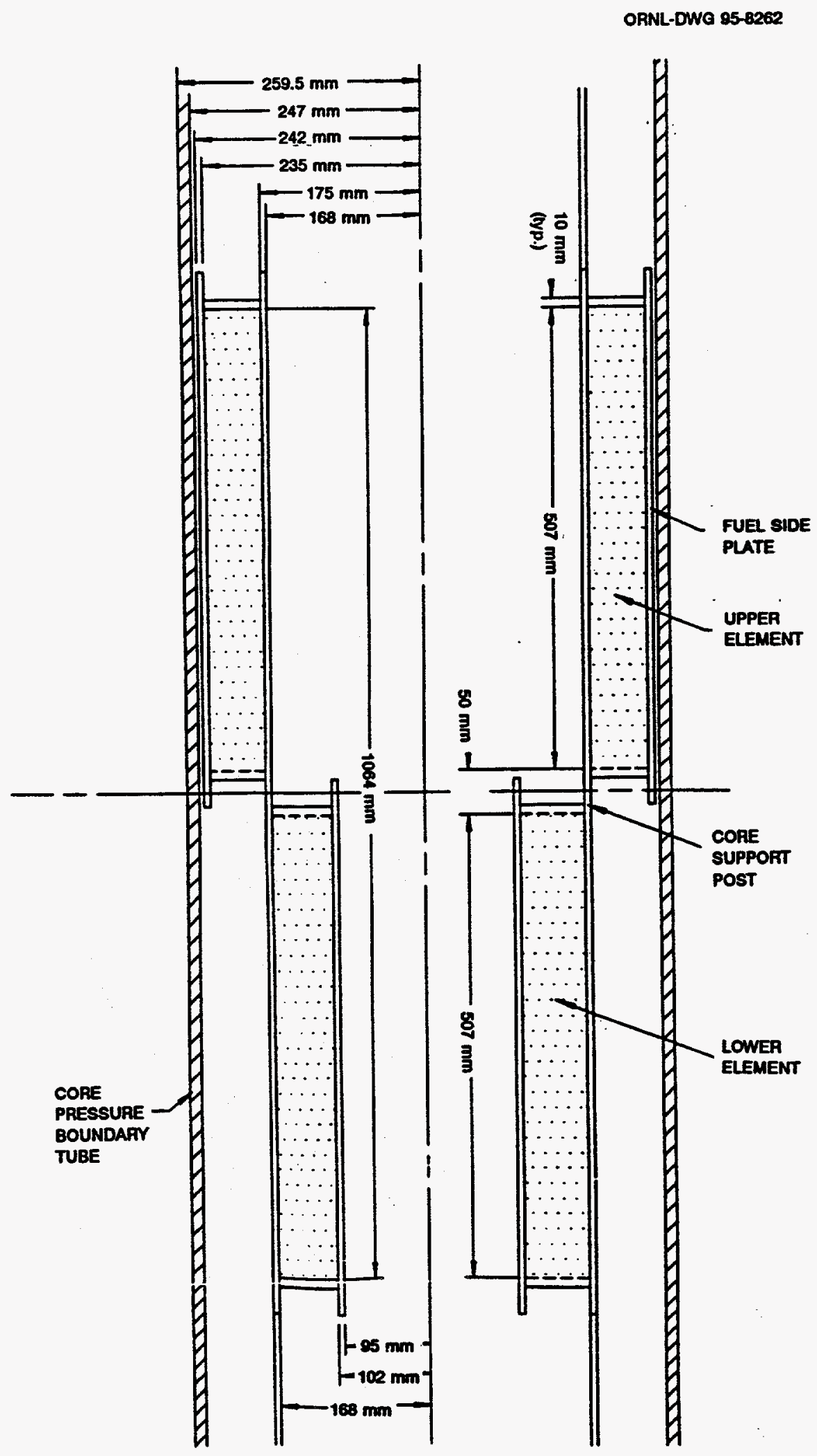

Fig. 2. Conceptual core design. 


\section{MILLER'S THEORY EXTENDED TO INVOLUTE PLATES}

The involute fuel plates in the ANS reactor have fluid flowing between them at high velocities. The early design of the reactor was based on a desired flow velocity of $27 \mathrm{~m} / \mathrm{s}$, a significant increase over the flow velocity of $15.5 \mathrm{~m} / \mathrm{s}$ for which the High Flux Isotope Reactor was designed. The high velocity in the ANS design required that the effects of the fluid velocity be carefully examined.

Involute plate deflection due to coolant flow was determined. ${ }^{6}$ This early work was based on D. R. Miller's theory in which he developed a method of determining the hydraulically induced deflection in parallel flat and curved fuel plate assemblies. ${ }^{7}$ He predicted a sudden collapse of the fuel plates, when the flow reached a calculated value of velocity, due to instability in the plates. The term used for this velocity is the critical velocity. Miller's theory was extended to involute plates by coupling elastic finite element models with Bernoulli's equation.

To determine the critical velocity in a fuel plate, a finite element model of an involute fuel plate (Fig. 3) was developed, and the deflection of the plate, due to a given pressure, was determined. PATRAN was used to develop the finite element model of the fuel plate; the finite element code ADINA was used to determine the deflection. The change in cross-sectional area for the channel was found by integrating the deflection curve. The result was then multiplied by two to account for the plates on each side of the channel. This value was then divided by the original channel cross-sectional area to give the per-unit change in channel cross section. The per-unit change in the channel cross-sectional area is used to solve Bernoulli's equation for the velocity. Using the method described above, the critical velocity of several flat plates was determined by modeling the plates with two-

ORNL-OWE $95-8263$

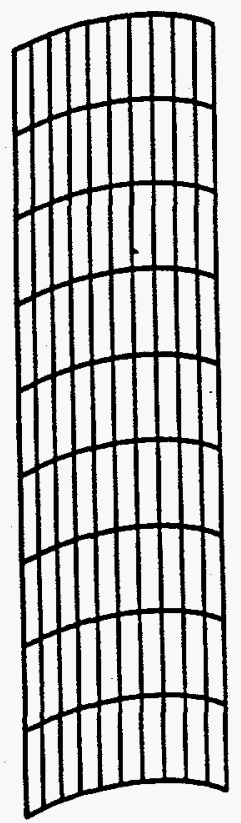

Fig. 3. Finite element model of involute plate. 
dimensional finite elements. The results of these analyses were compared with Miller's closed form equation for critical velocity. The comparison of the results showed that this method gives the same critical velocity for flat plates as that in Miller's equation.

This method of determining the critical velocity of involute fuel plates was used for several purposes in the early design of the ANS reactor, one of which was in performing parameter studies on involute fuel plates being considered for the ANS reactor. These analyses assisted in determining the dimensions for the upper and lower core for the preconceptual ANS core. Table 1 shows the results of some of these analyses. The values in the table do not include a factor of safety. The correct factor of safety is based on the boundary conditions on the plates.

Table 1. Parameter study critical velocity $(\mathrm{m} / \mathrm{s})$

\begin{tabular}{lll||lcc}
\hline \multicolumn{3}{c}{ Lower fuel plates } & \multicolumn{3}{c}{ Upper fuel plates } \\
\hline $\begin{array}{c}\text { Inner } \\
\text { radius }\end{array}$ & $\begin{array}{c}\text { Outer } \\
\text { radius }\end{array}$ & $\begin{array}{c}\text { Critical } \\
\text { velocity }\end{array}$ & $\begin{array}{c}\text { Inner } \\
\text { radius }\end{array}$ & $\begin{array}{c}\text { Outer } \\
\text { radius }\end{array}$ & $\begin{array}{c}\text { Critical } \\
\text { velocity }\end{array}$ \\
\hline 102 & 166.5 & 44.38 & 173.5 & 236 & 44.16 \\
102 & 167.5 & 43.33 & 174.5 & 238 & 43.35 \\
102 & 170.5 & 40.33 & 177.5 & 246 & 39.62 \\
102 & 171.5 & 39.37 & 178.5 & 248 & 38.92 \\
150 & 205 & 52.14 & 212 & 263 & 51.02 \\
150 & 209 & 48.52 & 216 & 270 & 48.19 \\
150 & 209.5 & 47.92 & 216.5 & 272 & 46.97 \\
180 & 229 & 55.56 & 236 & 281 & 55.09 \\
180 & 233.5 & 51.21 & 240.5 & 289 & 51.24 \\
180 & 234 & 50.76 & 241 & 290 & 50.76 \\
210 & 254 & 58.29 & 261 & 302 & 56.79 \\
210 & 258 & 54.00 & 265 & 309 & 54.13 \\
210 & 258.5 & 53.49 & 265.5 & 310 & 53.55 \\
\hline
\end{tabular}

Analyses were performed using Miller's theory extended to involute plates to determine the effect that various boundary conditions, along the length of the fuel plates, had on the critical velocity. Cases were considered where the edges were completely fixed and where the boundary conditions on the edges were various combinations of fixed and simply supported. The critical velocity was not affected much by the various edge conditions until a large part of the plate's edge was simply supported. The involute plate used in this analysis had an inner diameter of $120 \mathrm{~mm}$ and an outer diameter of $213.225 \mathrm{~mm}$. Table 2 lists the results of varying the edge conditions on this plate. From these analyses a factor of safety for the critical velocity was determined. Using a typical factor of safety of 1.5 does not take into account the fact that the plates in the actual core are not completely fixed along the edges but are closer to $75 \%$ simply supported and $25 \%$ fixed. Based on these analyses, the typical value of 1.5 should be multiplied by the ratio of the critical velocity of a fixed plate to the critical velocity of a $75 \%$ simply supported plate. Based on these analyses, the safety factor was determined to be 1.875 .

Using this method, the effects of adding combs at the entrance and exit of the plate assembly were also studied. The result of this analysis showed that the addition of two combs at the top and bottom of the plates would significantly raise the critical velocity. For the case with $100 \%$ fixed edges, the addition of the combs would raise the critical velocity from 46.03 to $62.70 \mathrm{~m} / \mathrm{s}$.

This type of analysis served as a starting place for the design of the ANS fuel plates. This method uses Miller's basic theory and extends it to involute plates. The fact that this method considers the problem to be one of instability is questioned based on the results of experimental work. ${ }^{8}$ As 
Table 2. Critical velocity from fixity studies

\begin{tabular}{lc}
\hline Boundary conditions & Critical velocity $(\mathrm{m} / \mathrm{s})$ \\
\hline 100\% Fixed edges & 46.03 \\
$50 \%$ Simply supported & 40.56 \\
$75 \%$ Simply supported & 36.52 \\
$100 \%$ Simply supported & 3.99 \\
\hline
\end{tabular}

experimental data became available, it was clear that the Miller approach did not correlate with the data. Miller's basic assumption of a sudden collapse does not describe the problem. Test results do not show a sudden collapse but rather a gradual increase in deflection with an increase in flow velocity.

W. F. Swinson assumes that parallel flow occurs between the plates rather than constant mass flow, as Miller assumed. This assumption leads to a stable plate deflection as opposed to a sudden plate collapse, which Miller's theory predicts. Swinson developed an analytical method that he termed the Dynamic Pressure approach. ${ }^{9}$ This method is based on parallel flow theory and determines the velocity that will cause adjacent plates to touch. In comparing the results of this method with experimental results, Swinson claims that the dynamic pressure is an upper limit. Swinson points out that because the problem is one of highly turbulent flow between the channels, it is difficult to predict the behavior of the plates using a strictly analytical method. He developed a method that combines empirical and analytical solutions. ${ }^{10}$ This method uses experimental data to develop an empirical solution for assigning the flow load to a plate and then, using an analytical solution, predicts the elastic response of the plate to this load. 
. 


\section{FLOW BLOCKAGE EFFECTS ON ADVANCED NEUTRON SOURCE FUEL PLATES}

In designing the ANS involute fuel plates, one concern is the effect that a blockage in one of the channels would have on the fuel plates. Using the program FLUENT, T. K. Stovall calculated the pressure in a partially blocked and an unblocked channel. FLUENT is a finite difference, computational, fluid dynamics code. The analyzed case was for the lower fuel plate, from the twoelement core, with a fluid velocity of $25 \mathrm{~m} / \mathrm{s}$ with one channel $25 \%$ blocked. T. K. Stovall furnished pressure data from two FLUENT runs: one from an unblocked channel and one from a channel with the inlet blocked $25 \%$ at the inside edge. The assumption for the finite element analysis was that a plate was between the unblocked channel and the partially blocked channel.

To use the pressure data from FLUENT, it was necessary to convert the data to a format compatible with the finite element modeling package IDEAS. A translator to read in the pressure data from the FLUENT program and to write out data for the finite element modeling program IDEAS was written. The translator calculated the pressure difference on the fuel plate between the partially blocked channel and the unblocked channel. The translator also wrote an input file for IDEAS that contained the finite element mesh and the pressure difference at each node. Figure 4 shows the finite element mesh of the fuel plate; Fig. 5 shows the calculated pressure difference on the fuel plate. The finite element mesh is finest at the plate inlet where the blockage occurs. This is the location where the plate has the largest pressure difference.

The finite element program ABAQUS was used to perform the finite element stress analysis. The results of this analysis of a $25 \%$ edge blockage show that the maximum stress in the fuel plate is above the yield stress but below the ultimate stress. For 6061-T0 aluminum at room temperature, the yield strength is about $57 \mathrm{MPa}$, and the ultimate strength is about $135 \mathrm{MPa}$. The maximum stress in the fuel plate between the partially blocked channel and the unblocked channel is $78.4 \mathrm{MPa}$. This is located along the inside edge of the plate near where the blockage was modeled (Fig. 6). This analysis sets up the groundwork for analyzing other fuel element core blockage configurations. 


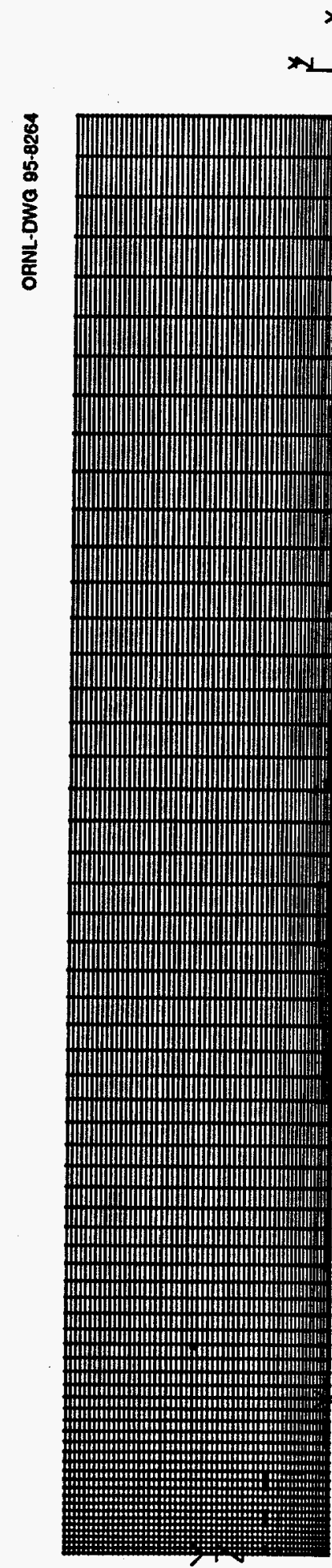

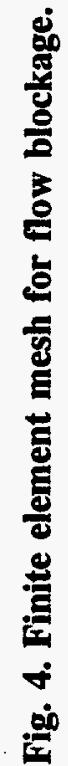




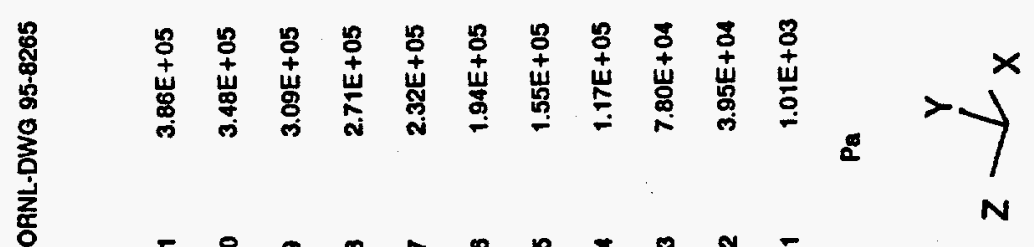

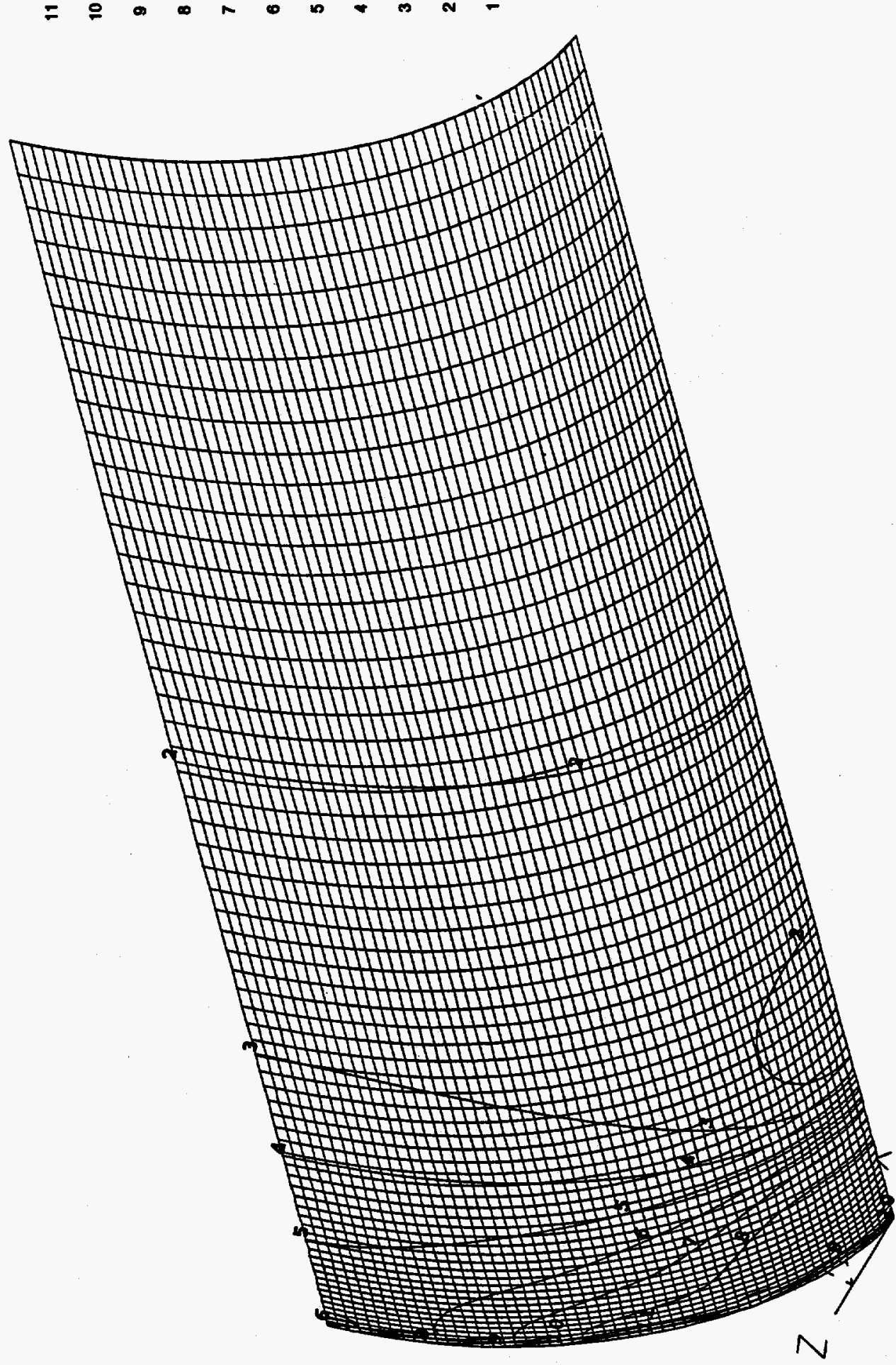

雚 

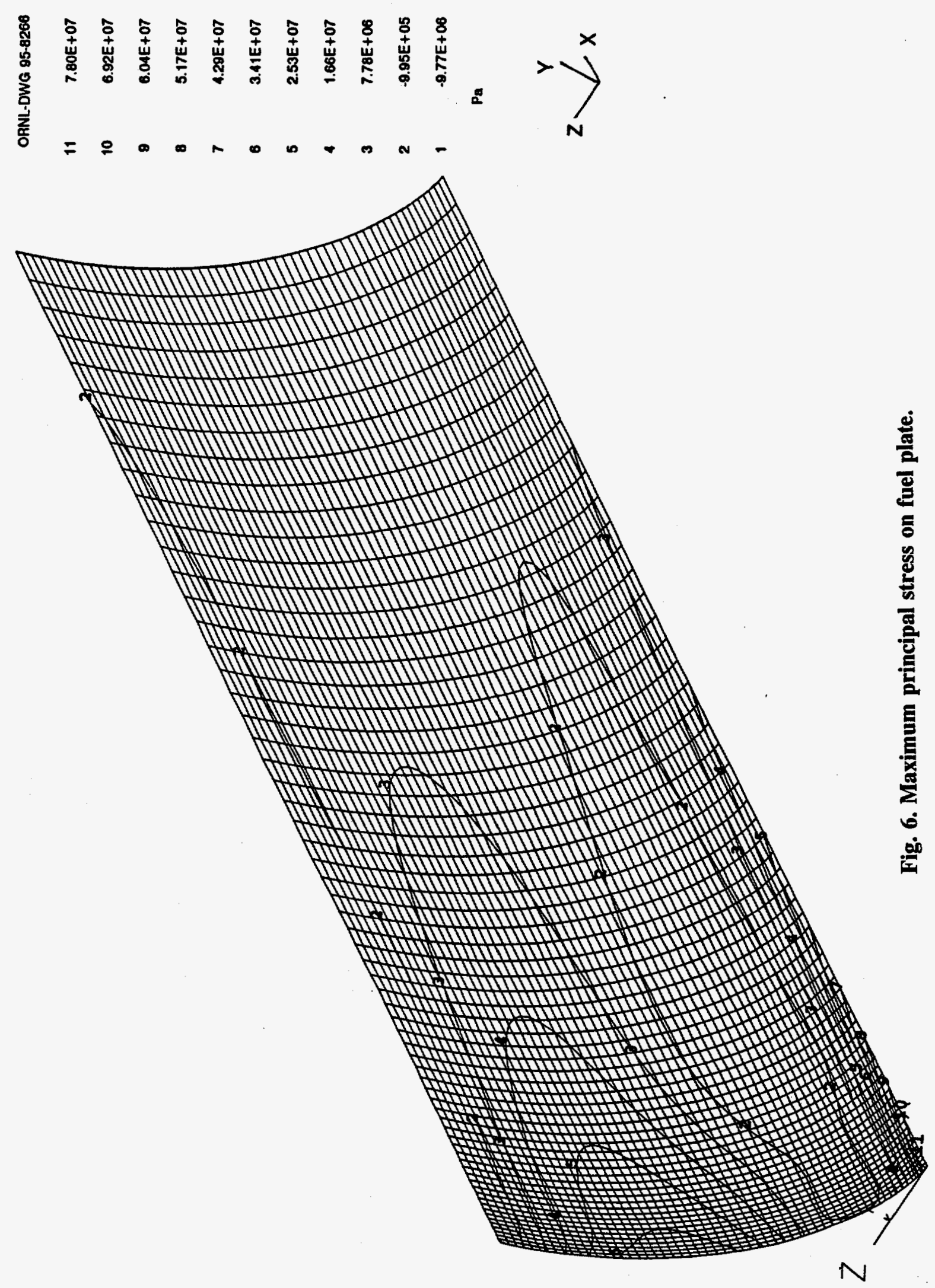


\section{TEMPERATURE EFFECTS ON GAP BETWEEN ADVANCED NEUTRON SOURCE FUEL PLATES}

Variations occurring in the temperature profiles of the plates in the ANS core are due to a nonuniform power distribution in the plates and the differences in gaps between the plates. The case analyzed assumes that the hottest plate in the core and the coldest plate in the core are adjacent. This case gives the largest change in gap. It is an iterative problem because the change in gap effects the temperature profile. These analyses were performed to furnish input to the thermal analyses.

Thermal stress analyses to determine the change in gap between hot and cold ANS fuel plates were performed using temperature profiles received from W. R. Nelson. These temperature profiles included the hottest and coldest plates, based on statistical analysis, for both the upper and the lower ANS fuel elements. The finite element model used in these analyses consisted of two upper and two lower fuel plates. From this model, the change in gap between the statistical hot and cold plates was determined using the finite element program ABAQUS. Figure 7 shows the finite element model used for the thermal stress analyses. Depicted are the two upper and two lower plates with the gap between them and the portion of the side walls used in the analyses. The model of the upper and lower fuel plates consists of 512 8-node shell elements. Periodic boundary conditions were imposed on the model to simulate analyzing the whole core by modeling only two upper and two lower fuel plates along with a portion of the cylinders around the plates. The middle cylinder was fixed at the bottom in the axial and circumferential directions. The inner and outer cylinders are designed to rotate freely to relieve some of the stress in the fuel plates.

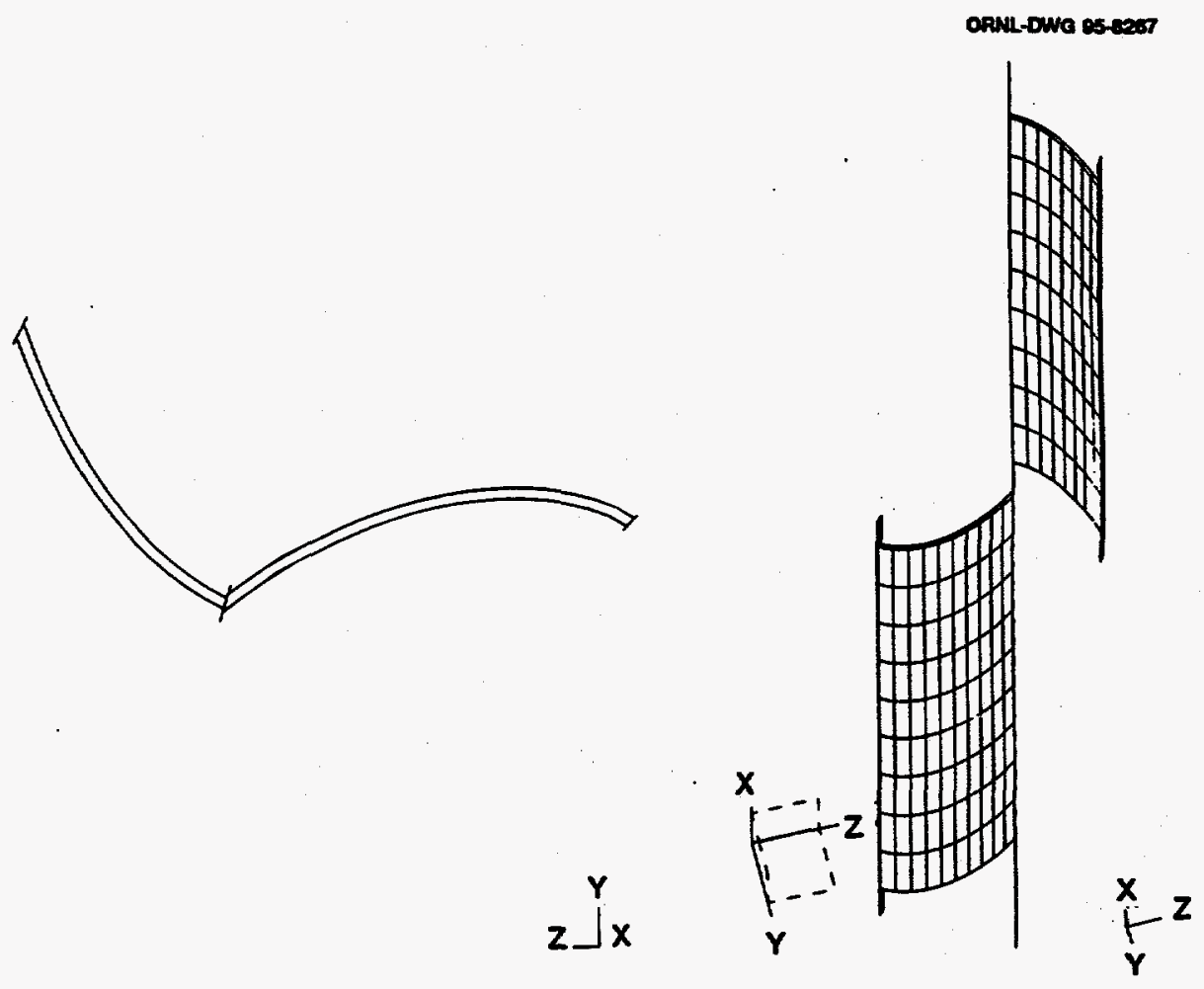

Fig. 7. Finite element model for thermal analysis. 
For the analyses, the temperature data from W. R. Nelson was applied to the fuel plates along with a constant side wall temperature of $51.9^{\circ} \mathrm{C}$. The data from W. R. Nelson did not contain temperatures for the side walls, but the temperatures on the plates along the entrance and along the sides adjacent to the side walls were all $51.9^{\circ} \mathrm{C}$. The assumption of the constant side wall temperature was based on the fact that the plates were $51.9^{\circ} \mathrm{C}$ adjacent to the side walls. One of the upper fuel plates modeled was loaded with the temperature profile for an upper hot plate between two narrow channels; the other upper fuel plate modeled was loaded with the temperature profile for an upper cold plate between two wide channels. Likewise, the two lower plates modeled were loaded with the temperature profiles for a lower hot plate between two narrow channels and a lower cold plate between two wide channels. Figures 8 and 9 show the lower and upper fuel plate temperature profiles respectively.

The results from the analysis of the lower ANS fuel plates show that the gap between the hot and cold plates does change. Figure 10 shows the change in gap, magnified by $5,59 \mathrm{~mm}$ below the top of the fuel plates. The maximum change in gap between the lower fuel plates is $0.200 \mathrm{~mm}$. This maximum change in gap occurs about $59 \mathrm{~mm}$ from the top of the plates at a radial position of about $140 \mathrm{~mm}$. Table 3 shows the change in gap between hot and cold lower fuel plates vs the radial position $59 \mathrm{~mm}$ from the top of the plates. The maximum occurs at this point because the temperature profiles have the maximum temperature difference at this location. Because the initial gap between the plates is $1.27 \mathrm{~mm}$, the gap changes a maximum of $15.7 \%$.

The analysis of the upper ANS fuel plates produced similar gap changes. The maximum change in gap between the upper hot and cold plates is $0.288 \mathrm{~mm}$. The location of the maximum value is about $59 \mathrm{~mm}$ from the top of the plate and at a radial position of about $208 \mathrm{~mm}$. Figure 11 shows the change in gap magnified by 5 . Table 4 lists the change in gap between hot and cold upper fuel plates vs the radial position $59 \mathrm{~mm}$ from the top of the plates. As is the case in the lower fuel plates, the maximum deflection occurs where the maximum temperature difference between the two plates occurs. The upper fuel plate gap between the hot and cold fuel plates changes $22.7 \%$.

The analyses of the upper and lower plates show that the axial stresses in the plates from the thermal loads are high. Figures 12 and 13 show the axial stress for the lower and upper fuel plates respectfully. The results of these analyses show that the lower fuel plates have a maximum axial stress of 114.5 MPa and that the upper plates have a maximum axial stress of $133.1 \mathrm{MPa}$. Both of these values are above the yield strength of the fuel plate material, 6061-T0 aluminum. For 6061-T0 aluminum the yield strength is about $57 \mathrm{MPa}$ at room temperature, and the ultimate strength at room temperature is about $135 \mathrm{MPa}$. Both of these values drop off as the temperature goes up. Figure 14 is a plot of the tensile strength of 6061-T0 aluminum as a function of temperature. ${ }^{10}$ The temperature of the plates at the location of the maximum stresses is about $52^{\circ} \mathrm{C}$; therefore the maximum stresses in the plates are below the ultimate strength. These high axial stresses are occurring in the fuel plates because the side wall temperatures are much cooler than the plate temperatures. The hot plates are attempting to expand more than the cool side walls; thus, a high axial stress results. An analysis was done where the side wall temperatures were assumed to be $68.6^{\circ} \mathrm{C}$ instead of $51.9^{\circ} \mathrm{C}$. For this case the maximum axial stress in the lower fuel plate was $95.15 \mathrm{MPa}$, and the maximum axial stress in the upper fuel plate was $121.35 \mathrm{MPa}$. This case shows that by reducing the difference in temperature between the side walls and the fuel plates, the axial stress can be reduced.

Several observations were made from the thermal stress analyses of the upper and lower fuel plates. First, the difference in temperature of a hot and a cold fuel plate adjacent to each other can change the gap between the plates by as much as $22.7 \%$. Second, the large difference in temperature between the side walls and the fuel plates causes a maximum stress that is above the yield strength of the material. The actual temperature of the side walls needs to be known to determine the axial stress in the fuel plates. The results of the thermal stress analyses were furnished to D. G. Morris to be input to the thermal analyses. 

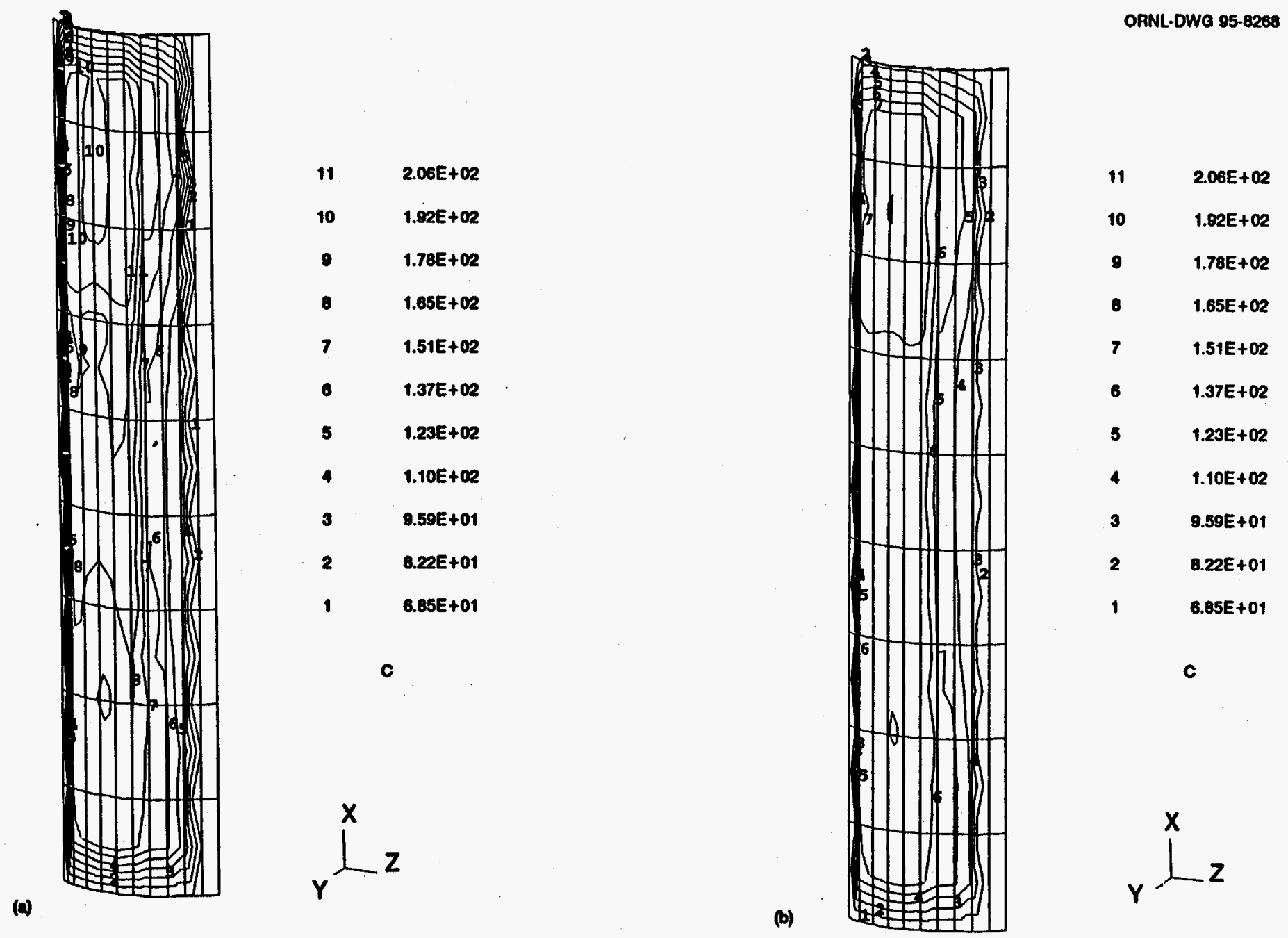

ORNL-DWO 95-8268

Fig. 8. Lower fuel plate temperature profiles: (a) lower hot plate and (b) lower cold plate. 

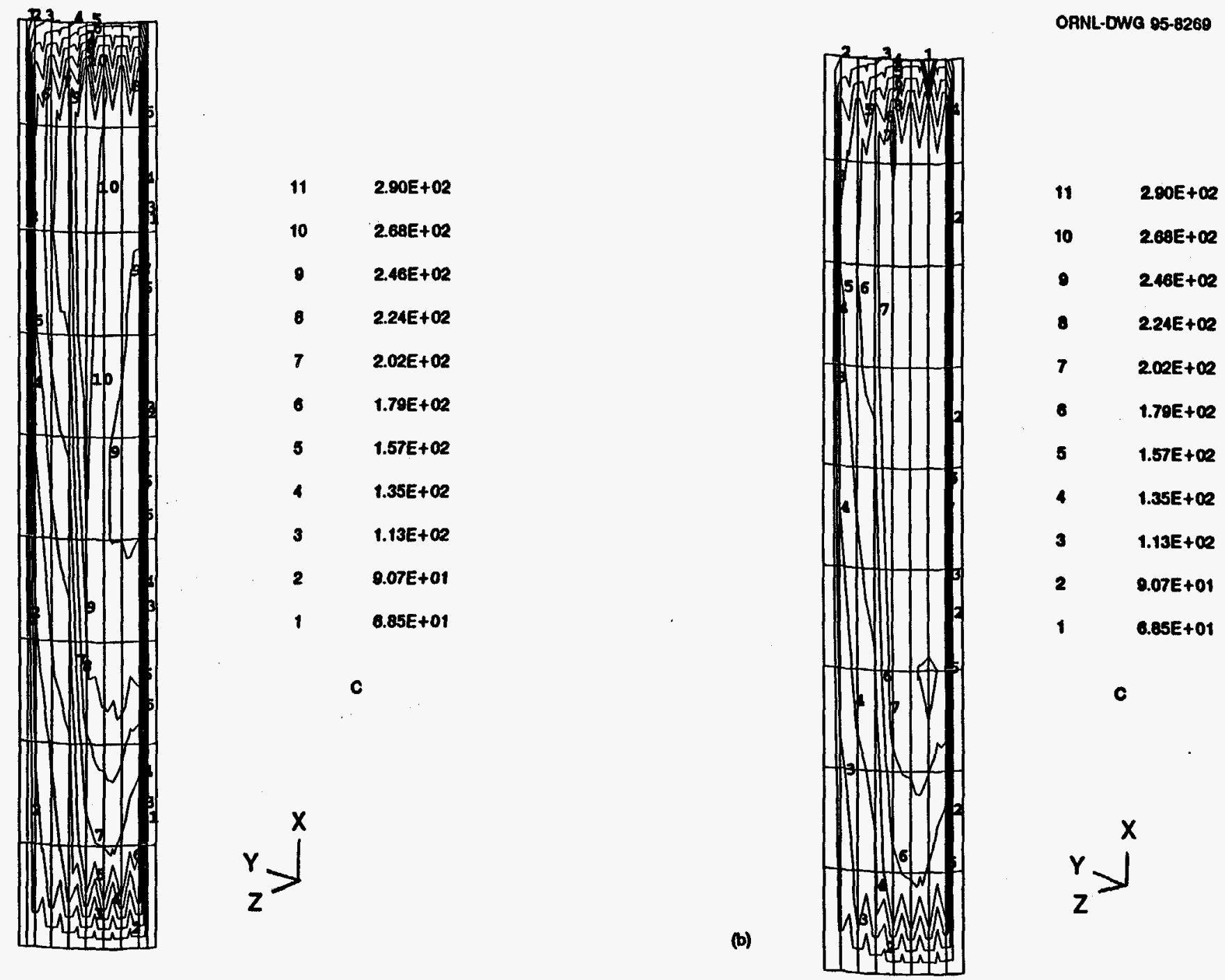

Fig. 9. Upper fuel plate temperature profiles: (a) upper hot plate and (b) upper cold plate. 
Table 3. Lower plate comparison of change in gap between hot and cold plates $59 \mathrm{~mm}$ from top of plates

\begin{tabular}{cc}
\hline Radius $(\mathrm{mm})$ & $\Delta$ - Displacement $(\mathrm{mm})$ \\
\hline 98.5 & 0 \\
103.4 & 0.002 \\
108.1 & 0.003 \\
112.5 & 0.025 \\
116.8 & 0.061 \\
121.0 & 0.099 \\
125.0 & 0.136 \\
128.9 & 0.168 \\
132.6 & 0.182 \\
136.3 & 0.200 \\
139.9 & 0.198 \\
143.3 & 0.186 \\
146.7 & 0.163 \\
150.0 & 0.133 \\
153.3 & 0.100 \\
156.5 & 0.066 \\
159.6 & 0.038 \\
162.7 & 0.016 \\
165.7 & 0.002 \\
168.6 & 0.001 \\
171.5 & 0 \\
\hline
\end{tabular}

ORNL-DWa $95-8270$

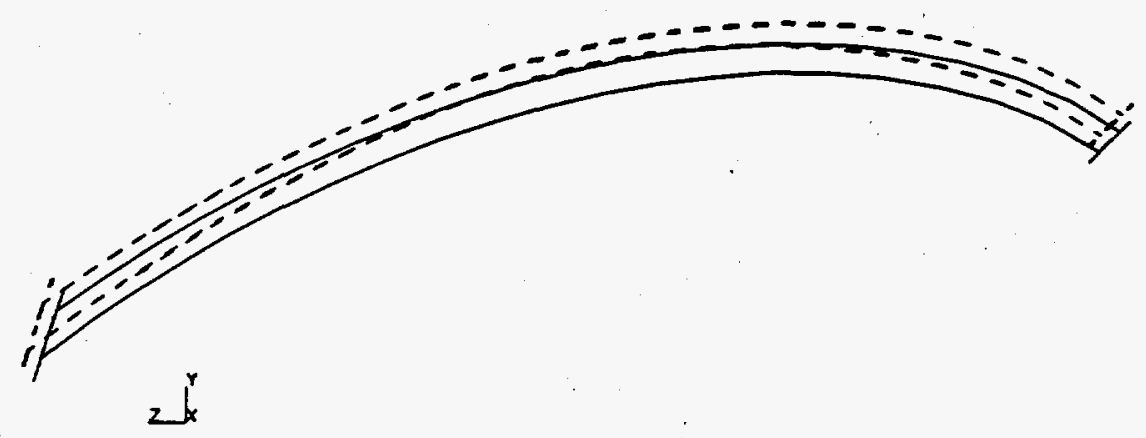

SOLID LINE: UNDEFOPMED DASHED UNE: DEFORMED

Fig. 10. Lower fuel plate deflection. 
Table 4. Upper plate comparison of change in gap between hot and cold plates $59 \mathrm{~mm}$ from top of plates

\begin{tabular}{cc}
\hline Radius $(\mathrm{mm})$ & $\Delta$-Displacement (mm) \\
\hline 171.5 & 0 \\
176.4 & 0.007 \\
181.2 & 0.036 \\
185.9 & 0.084 \\
190.5 & 0.146 \\
194.9 & 0.205 \\
199.3 & 0.253 \\
203.6 & 0.283 \\
207.7 & 0.288 \\
211.8 & 0.271 \\
215.8 & 0.232 \\
219.8 & 0.181 \\
223.7 & 0.125 \\
227.5 & 0.073 \\
231.2 & 0.032 \\
234.9 & 0.007 \\
238.5 & 0 \\
\hline
\end{tabular}

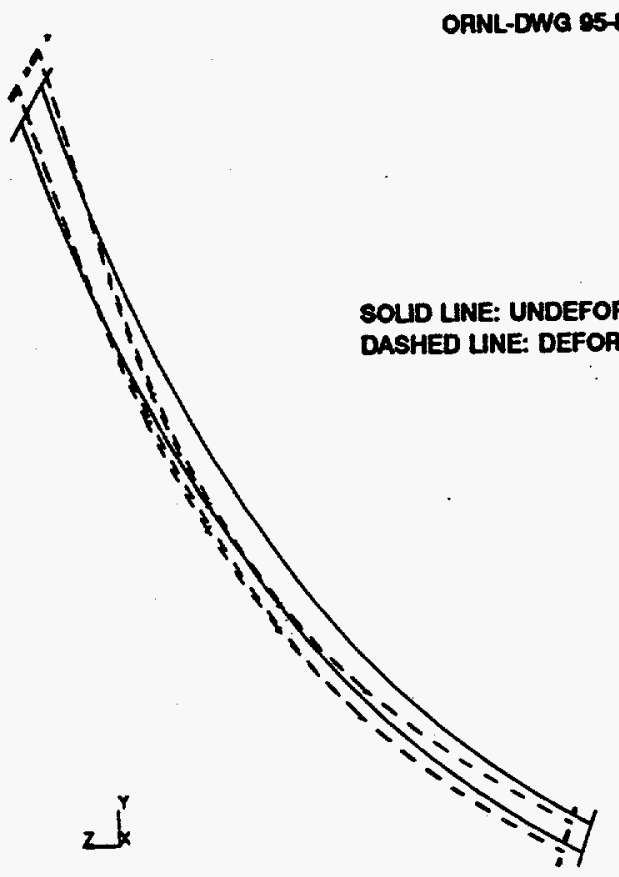

Fig. 11. Upper fuel plate deflection. 

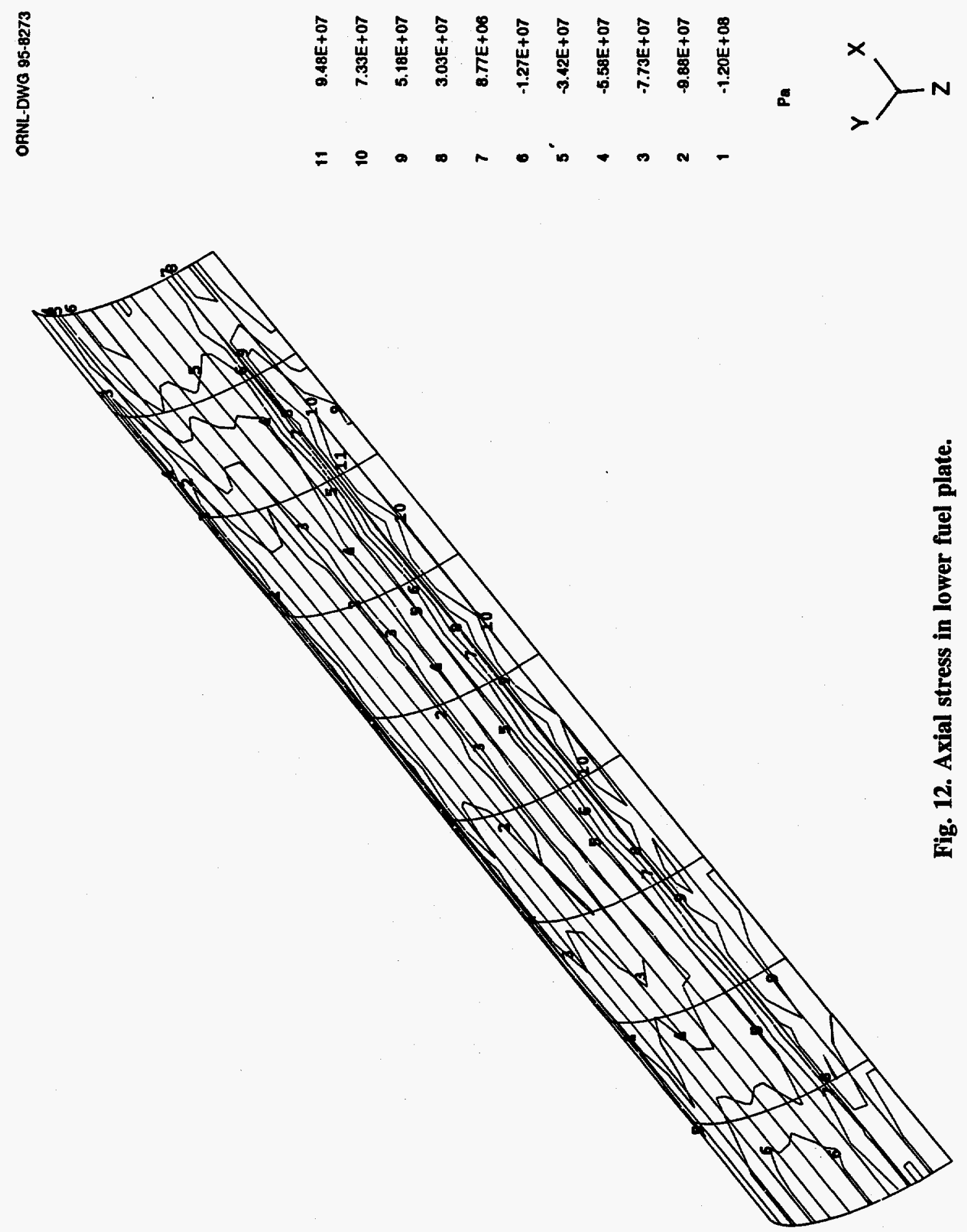

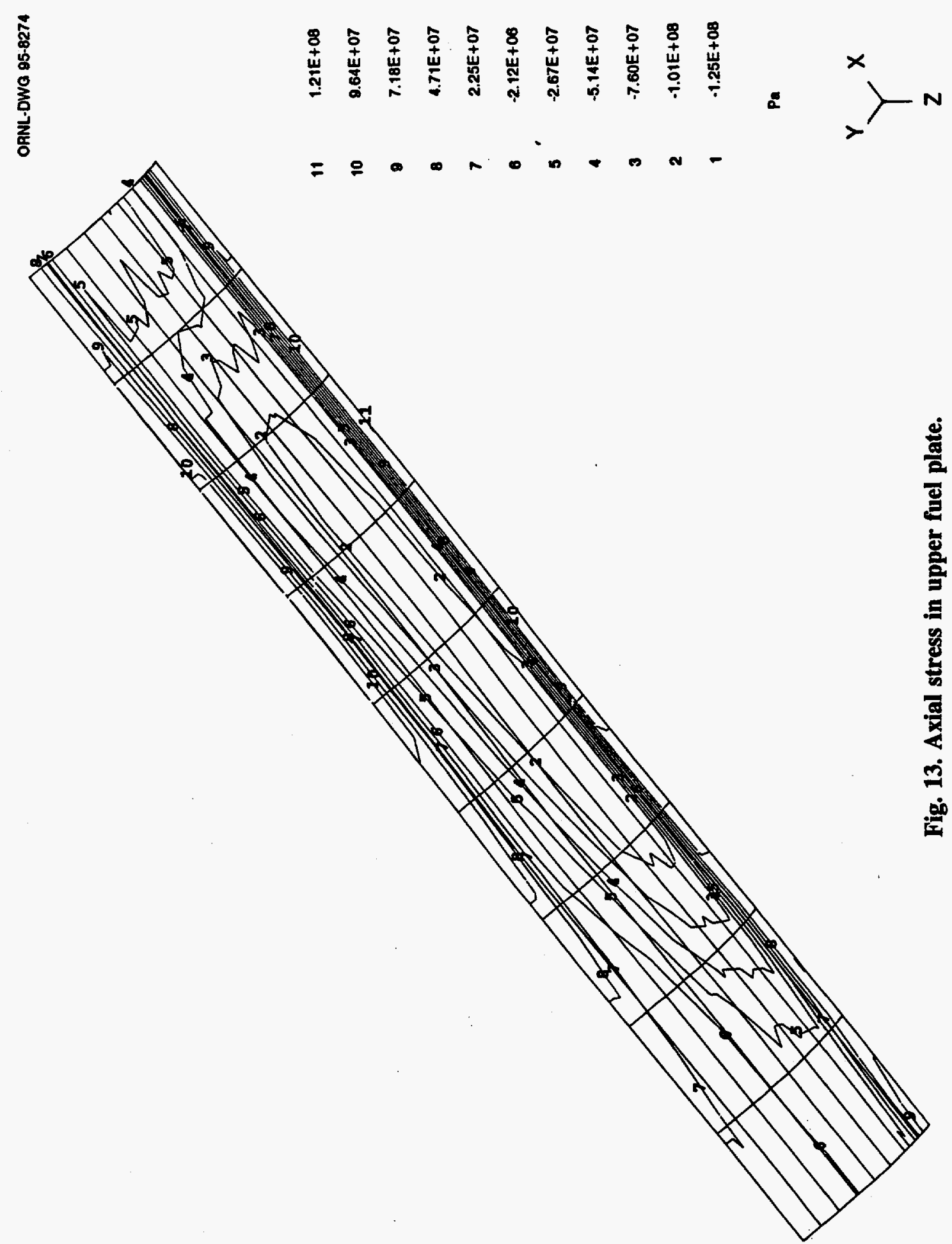


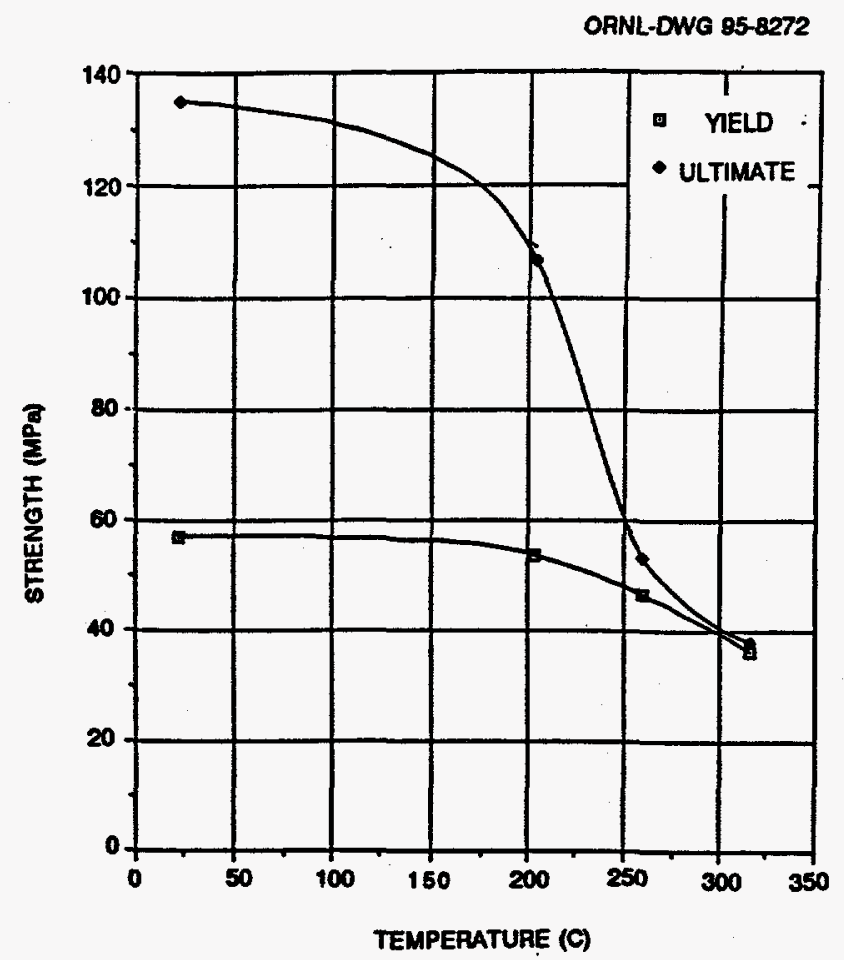

Fig. 14. Tensile strength of 6061-T0 aluminum as a function of temperature. 


\section{CONCLUSION}

Analyses on the conceptual design of the ANS reactor involute fuel plates, shown in Fig. 2, revealed problems with the design. The fuel plates in the original two-element core design, with coolant flowing between the plates at high velocities, have stresses above the yield strength for the fuel plate material.

The study of the critical velocity of the involute fuel plates discussed is an extension of Miller's theory: from flat plates to involute plates. Based on this method, the critical velocity of the conceptual design of the fuel plates is below $27 \mathrm{~m} / \mathrm{s}$ after a factor of safety of 1.875 is included. This method of evaluating the plates was replaced by other methods that more closely compare with experimental data.

The analysis of the effect of a flow blockage on the fuel plates shows that the stress in the plate is above the yield strength for the fuel plate material, 6061-T0 aluminum. The case analyzed was a lower fuel plate between an unblocked channel and a channel $25 \%$ blocked with a flow velocity of $25 \mathrm{~m} / \mathrm{s}$. The maximum stress in the fuel plate between the partially blocked channel and the unblocked channel is $78.4 \mathrm{MPa}$. The yield strength of the material is $57 \mathrm{MPa}$.

The effect of temperature on the fuel plates shows that for an adjacent hot and cold fuel plate, the gap between the plates may change as much as $22.7 \%$. These analyses were done on the upper and lower fuel plates of the conceptual design. The axial stress in the fuel plates was above the yield stress for 6061-T0 aluminum. The upper hot fuel plate had an axial stress of $133.1 \mathrm{MPa}$; the lower hot fuel plate, 114.5 $\mathrm{MPa}$. The axial stress is caused by the difference in temperature between the fuel plates and the side walls. For this analysis it was assumed that the side walls were at a constant temperature of $51.9^{\circ} \mathrm{C}$. The axial stress can be reduced by increasing the side wall temperature.

The design of the ANS fuel plates was not finalized. A design of a three-element core was proposed, and the desired coolant flow velocity between the plates was reduced to $20 \mathrm{~m} / \mathrm{s}$. This design was not evaluated using the above analyses. Further work would have to be done to determine if the stresses and deflections in the three-element core would be acceptable. 



\section{REFERENCES}

1. F. J. Peretz, Conceptual Design Report-Summary, ORNL/ANS/INT/34/51, Martin Marietta Energy Systems, Oak Ridge Natl. Lab., June 1993.

2. ADINA, Finite Element Program for Automatic Dynamic Incremental Nonlinear Analysis, ADINA Engineering, Watertown, Mass., December 1984.

3. ABAQUS/Standard, General Purpose Finite Element Structural Code, Hibbit, Karlsson, and Sorensen, Pawtucket, RI, 1993.

4. PATRAN, Finite Element Mesh Generator, PDA Engineering Software Products Division, Costa Mesa, Calif., 1984.

5. SDRC I-DEAS Master Series, Finite Element Mesh Generator, Structural Dynamics Research Corp., Milford, Ohio, 1994.

6. R. C. Gwaltney and C. R. Luttrell, "Critical Flow Velocity for Involute Parallel Fuel Plate Assemblies,” Trans. Am. Nucl. Soc., 57, 298 (1988).

7. D. R. Miller, "Critical Flow Velocities for Collapse of Reactor Parallel Plate Fuel Assemblies," J. Eng. Power, Trans. ASME 83-95 (April 1960).

8. W. F. Swinson, R. L. Battiste, C. R. Luttrell, and G. T. Yahr, Follow-up Fuel Plate Stability Experiments and Analyses for the Advanced Neutron Source, ORNL/TM-12629, Martin Marietta Energy Systems, Oak Ridge Natl. Lab., November 1993.

9. W. F. Swinson and G. T. Yahr, "Dynamic Pressure Approach to Analysis of Reactor Fuel Plate Stability," Tran. Am. Nucl. Soc., 61, 390, (June 1990).

10. W. F. Swinson, C. R. Luttrell, and G. T. Yahr, An Examination of the Elastic Structural Response of the Advanced Neutron Source Fuel Plates, ORNL/TM-12712, Martin Marietta Energy Systems, Oak Ridge Natl. Lab., September 1994.

11. W. R. Martin and J. R. Weir, Mechanical Properties of X8001 and 6061 Aluminum Alloys and Aluminum-Base Fuel Dispersion at Elevated Temperatures, ORNL-3557, Union Carbide Corp., Nucl. Div., Oak Ridge Natl. Lab., February 1964. 
,

,

$\because$

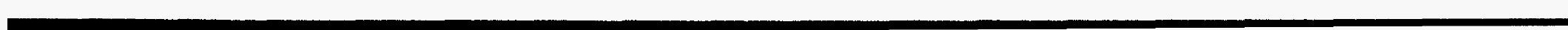


Internal Distribution

1. S. J. Chang

2. J. M. Corum

3. W. G. Craddick

4. G. F. Flanagan

5. R. G. Gilliland

6. R. C. Gwaltney

7. W. R. Hendrich

8-10. C. R. Luttrell

11. C. C. Queen

12. D. L. Selby
13. W. F. Swinson

14. C. D. West

15. G. T. Yahr

16-17. Central Research Library

18. Document Reference Section

19. ORNL Patent Section

20-21. Laboratory Records Department

22. Laboratory Records Department, RC

23-32. Y-12 Technical Library

\section{External Distribution}

33. U.S. Department of Energy, Oak Ridge Operations, FEDC, MS-8218, P.O. Box 2009, Oak Ridge, TN 37831-8218

34-35. Office of Scientific and Technical Information, P.O. Box 62, Oak Ridge, TN 37831 
